cytoplasmic inheritance. $\mathrm{He}$ goes on to present certain characteristics of Paramecium aurelia which are important from a genetical point of view. $\mathrm{He}$ then describes successively the data on 'killer' and 'sensitive' stocks, on the antigens of paramecium and on mating types. His concluding discussion is an attempt to evaluate the general importance of inheritance which is not due to chromosome genes. The subject-matter of the book arises mainly from the work of T. Sonneborn, and Dr. Beale's own investigations have greatly illuminated the genetical problems.

Among the many interesting phenomena, none exceeds in importance the observation that, with a given set of nuclear genes, alternative sets of surface antigens may exist. These sets are mutually exclusive, so that only one set may be found in any given individual. Which set does exist depends upon the previous history and present environment of the animal.

The subject-matter of these two books is quite different; the authors mention neither one another nor one another's most favoured research material. But despite this, both books are important contributions to the general problem of differentiation and modulation. They will be of great interest not only to entomologists and to geneticists, but also to all biologists who are interested in the controlling mechanisms which determine the characteristics of animals.

J. F. DANIELII

\section{PLANT GROWTH REGULATORS IN AMERICAN AGRICULTURE}

Plant Regulators in Agriculture

Edited by H. B. Tulkey. Pp. $x+269$. (New York John Wiley and Sons, Inc.; London : Chapman and Hall, Ltd., 1954.) 44s. net.

THIS book is in effect a symposium, written by a panel of experts, "for the many who have been puzzled ... at their seeming inability to grasp the significance of plant growth regulators, what they are, how they operate and where they belong in agriculture". Only the last-named point has been satisfactorily and consistently covered by this book - that is, their place in agriculture. Thus the very wide range of practical application of those synthetic organic chemicals, now unfortunately come to be known almost universally as plant growth 'regulators', has been thoroughly surveyed and our knowledge brought up to date. Comprehensive as this review may be for the American farmer and fruit-grower, its appeal outside the American Continent will be more limited, since little attention is paid to problems from other parts of the world. Thus only one page out of the 224 of text is devoted to weed control in small-grain cereals-a major interest of European farmers. Its value for tbe non-American is further offset by the exclusive use, in some chapters, of the common American name for crop plants. Thus "snap bean" would mean so much more to a European if its botanical name were sppended.

An exposition of the biological significance and mode of action of plant 'regulators' is only spasmodically attempted, despite three somewhat 'bitty' introductory chapters which set out elementary facts and general principles. The consequent confusion in the mind of the layman will not be helped by the fact that the whole polyglot collection of physiologically active compounds are only too frequently considered purely in relation to the general growth symptoms they cause in the plant, and with little regard to the wide diversity of their fundamental actions in the cell. After all, both influenza and a brick on the head will cause a headache.

The main deficiency of this book is therefore the absence of a unifying theme, and this arises from the symposium technique of writing a book. However well meaning an editor may be, it will be difficult for him, short of rewriting whole sections of text, to mould difficult subject-matter such as this into a connected story and to eliminate the overlaps arising between articles of writers with competing interests. It is to be regretted that many of these overlaps were not avoided by allowing the whole of a given field of application to be covered by one author instead of sharing it out between a number of narrow specialists. Some of the contributors have produced excellent articles fulfilling completely the aims set out for the book as a whole. Chapters of this kind are those on parthenocarpy and fruit development in relation to plant regulators; abscission and plant regulators; and plant regulators for weed control in the tropics. Fewer contributions of this quality, each covering one major aspect of plant growth control, would have yielded a much better book.

A final chapter, dealing exclusively with apparatus for the application of chemical growth regulators, will be of considerable interest, although its direct value to the user outside America will depend on the type of equipment available in his country. The book is well produced, and there are many excellent photographic and line illustrations and tables giving details of plant responses to specific regulator treatments in America.

L. J. AUDUS

\section{AMERICAN EPHEMERIS AND NAUTICAL ALMANAC}

The American Ephemeris and Nautical Almanac for the Year 1956

Pp. xvii +644. (Washington, D.C.: Government Printing Office, 1954.) 4 dollars.

7 HIS issue for 1956 of the "American Ephemeris and Nautical Almanac" follows its usual method of arrangement and is in many respects identical with that of the "Nautical Almanac" published in Great Britain. But in other ways it differs from its British counterpart in contents and also arrangement. A few of the points of difference may be noted here.

The American work gives the heliocentric longitude and latitude for all the planets, whereas the British one gives those for Mercury only; the former is a decided advantage, especially for those who have not got a copy of "Planetary Coordinates". The Besselian elements of the eclipses of the sun are given to the fifth significant decimal in the "Nautical Almanac", which is regarded as sufficiently accurate for computational purposes, but the "American Ephemeris" has seven significant figures; the last two figures can have little or no meaning, but this number has appeared for a long time. The same thing applies in other cases; for example, in mean places of stars, both in right ascension and declension, two extra figures are given by the "American Ephemeris" in the seconds. Under sunrise, sunset 